\title{
PRESENTATION:
}

\section{STUDIES ON LANGUAGE ATTITUDES AND POLICIES: PATHWAYS THROUGH GEOGRAPHIC, POLITICAL AND LANGUAGE BORDERS}

When this dossier on language attitudes and language policies was announced by the journal Ideação and within the scope of the UNESCO Chair on Language Policies for Multilingualism, we sought to bring together works that discussed the profound relationship between, on the one hand, knowledge socially (re) constructed about and in languages and, on the other, how decisions, strategies and actions towards them, their uses and their form, affect their places in society in the most varied domains. In view of this proposal, we had in mind two fields of investigation that bring together dense academic production both in Brazil and abroad - studies on language attitudes and on linguistic policies -, which are an interlinked, leading us to understand that both social and political dimensions influence language behaviours of those who use and build identities from them.

The predisposition to think, feel and react towards certain languages, varieties or language groups, that is, what we conventionally call language attitudes, consists of a multifaceted phenomenon that is related to the maintenance or disappearance of some languages, to the way the statutes of languages are attributed and agreed socially and politically, to the positions that the many languages of the world occupy in society influenced by power relations, to the implicit and explicit language policies, as well as to the way in which different speech and language communities speak of and about their languages. Thus, this dossier was outlined on the assumption that language policies, that is, decisions regarding languages and their uses in society, corroborate for the construction of knowledge, beliefs, opinions and stereotypes about languages and their places, a since such decisions are permeated by linguistic ideologies and discourses existing in a certain historical, political and cultural context that necessarily affect the way we think about languages and, why not say, those who speak them. 
Dossiê: Atitudes Linguísticas e Políticas Linguísticas: abordagens interdisciplinares

That being said, if there is something latent that runs through the many lines that compose the texts of this dossier, we can say that it is the assumption that language attitudes are on the agenda of the many ways of managing the forms and the use of languages. And, that interventions in relation to languages and their uses in society influence the formation and reproduction of language attitudes in different spheres, whether they are favourable or unfavourable. Thus, both language policies impact in the medium and long term to the construction of knowledge and feelings that make up what we call attitudes, as well as we verify the reverse movement of attitudes constitute the framework of orientations in language policy that might affect language management.

This dossier, as the title of this presentation announces, is composed of studies conducted by researchers who look at different geopolitical contexts and which, due to its diverse and interdisciplinary character, crosses geographical, political, linguistic, cultural and temporal boundaries, since the reader will find that there are texts that go back to different historical and cultural configurations in which attitudes and policies follow their step.

The path through which the pages of this dossier travel departs from a research in the State of Paraná, Brazil, where UNIOESTE and the Ideação team are geographically located. In the sequence, in a movement that is so important among researchers in our field of study and at our university, the dossier presents two studies that cross the border into Paraguay and show linguistic attitudes both favourable and unfavourable in relation to existing languages of that country: Spanish, Guarani and Jopará. After this approach to a region of South American space, the dossier advances to the other side of the Atlantic, unveiling the political-linguistic environment of the Republic of Cameroon, in Africa, and then, in another turn, we are led to Southeast Asia in a study about Timor-Leste. Finally, our attention is drawn to attitudes and linguistic policies in the Iberian Peninsula in the medieval period and the beginning of the Modern Age, having as perspective the interaction between language and religion. We therefore proceed, in the next few paragraphs, to briefly present the content of the texts that we are pleased to gather.

The first article, authored by Vanessa Marochi and Tadinei Daniel Jacumasso, built from research carried out on a CAPES thesis and dissertation database, analyses investigations on language attitudes developed between 2008 and 2018 in Paraná universities, with the aim of unveiling methodologies, procedures and results. Paraná, where Unioeste is also located, borders two Spanish-speaking countries in the western region, and 
Dossiê: Atitudes Linguísticas e Políticas Linguísticas: abordagens interdisciplinares

was (and still is) the arena of several migratory flows that contributed to the formation of the linguistic-cultural mosaic of this Brazilian state. The complex relations between language and society that are evident in sociolinguistically complex environments, as are the immigration contexts in which different languages (and linguistic groups) coexist and interact, stand out in the various academic works analysed by Marochi and Jacumassu and that point to the urgency for language policies that contribute to the maintenance and enhancement of the languages and cultures of different language communities. For, in general, as they argue, studies show that, although the languages of the different groups consist of a factor in maintaining culture and cultural identity and research participants express a deep sense of identification with their languages of immigration, there is a certain tendency to not maintain these languages among the communities, since the official national policies historically built in Brazil compress the uses and the importance of these languages in the face of a long process of homogenization in favour of the Portuguese language.

Following, we present the text of Martiny, Ribeiro and Cortez, all professors and researchers from the Federal University of Latin American Integration (UNILA), located in Foz do Iguaçu-PR, a municipality located on this intensely plurilingual border region. The study analyses an extension action on mediation of literary reading that crosses borders twice: first between Foz do Iguaçu, in Brazil and Ciudad del Este, in Paraguay and, later, between the university and a public school in the neighbouring country. The study analyses the linguistic attitudes of the project extension team and, with that, discusses the language policies declared and practiced by the university and in the educational institution where the action takes place, in whose country both Spanish and Guarani have the status of official languages and where a large part of the population speaks Jopará. From the analysis of the team's reports, in their relationship, approximation and reflection on the sociolinguistic environment of the school space, the authors conclude that the team's management of languages in that scenario contributed for them not to (re)produce unfavourable attitudes towards those languages and the culture of that school, valuing local knowledge and promoting harmonious relations in the encounter between different languages and cultures.

Following the same 'crossing' movement in that same border region, Santos' study presents us with a perspective on the attitudes of Paraguayan commerce workers in Ciudad del Este towards Jopará, that' third Paraguayan language 'derived from the contact between 
Dossiê: Atitudes Linguísticas e Políticas Linguísticas: abordagens interdisciplinares

Guarani and Spanish and which are present in the police news of the newspaper Diario Popular. His text, which derives from studies developed in master's and doctoral degrees, provides a link between the actions of linguistic planning in Paraguay and the formation of knowledge that tend to circumscribe the Jopará to areas of informal use. As he explains, this derives from deep power relations in the country that involve, for example, the ruling class and the school system in their ideologies about languages. His analyses show that the classifications, concepts and opinions in relation to the uses made of languages in the newspaper are formulated according to internalized, structured and structuring schemes, associated with the level of education of the workers participants of the research. These schemes orient their language attitudes in which the use of standardized forms of Guarani and Spanish are considered legitimate and, Jopará is acceptable as an expression of popular culture aimed at more informal contexts.

The studies that follow, as explained above, present us with unfamiliar contexts for this frontier where we are geographically and politically located. Hodieb's text, based on a post-colonial perspective, discusses the results of a survey conducted among 32 Cameroonians living in France with a view to understanding their attitudes towards French and indigenous languages in the Republic of Cameroon. As she affirms, the country's colonial past had profound implications for the country's linguistic configuration and the relationship of the population to its local, regional languages and those implanted during the shared governance of the colony between France and Great Britain. Hodieb explains that, while the British administration granted the people the use of their languages, French assimilationist policy was responsible for the marginalization of the country's many indigenous languages, subduing populations and causing intergenerational language loss. The author calls the 'Cameroonian paradox' the value that Cameroonians now attribute to their indigenous languages, feeling the need to recover them as part of the linguistic and cultural heritage, which highlights issues related to the identity and risks of extinction of these languages.

The penultimate article in this dossier, authored by Macedo and Savedra, aims to reflect on the relationship between language, time, and linguistic space, taking as a reference the sociolinguistic context of Timor-Leste. To this end, the researchers initially present three perspectives of space (linguistic space, social space, linguistic-political space), to subsequently discuss linguistic diversity in Timor-Leste in view of the political actions that culminated in interventions and forms of language management in a recognized multilingual 
Dossiê: Atitudes Linguísticas e Políticas Linguísticas: abordagens interdisciplinares

country, in which one of the official languages (Portuguese) does not coincide with the mother tongue of the majority of its inhabitants. Although the theme of attitudes is not central to the article, it stands out in the authors' reflections on the country's language policies and on the linguistic and social space in Timor-Leste, in which the issues of identity and linguistic resistance comes up.

The last text that makes up this dossier takes us back in time and looks at the use of language in the medieval period and at the beginning of what we know as the Modern Age. Gallego and Giménez-Eguíbar approach linguistic policies and attitudes from the point of view of the interaction between language and religion, more specifically discussing the relationship of Arabic with Islam on the one hand, and of romance with Christianity on the other in these two historical periods. As they explain, the association of the Arabic Ianguage with Islam, and that of romance and Latin with Christianity, predominated, respectively, both in the Iberian Peninsula under Islamic rule and when that space was under Christian rule. The analysed data suggest that the social and political linguistic attitudes that evolved from this association were structured differently: in the case of al-Andalus, interest in the language of Christians was minimal and the degree of 'Arabization' of Christians made any linguistic measures unnecessary, along with the fact that according to Islamic law no social homogenization or religious unification policy could be issued by the Islamic government. In contrast, in the 16th century, different social and political circumstances revealed attempts to convert Muslims to Christianity, with the aim of cultural assimilation. As an effect of power relations, attitudes and linguistic and cultural policies in the face of the language and religion of the 'others', the fate of the Arabic language was that of rejection and forgetfulness due to its connection with Islam.

In view of this panorama, we highlight this rich collection of articles that contribute to reflect on language attitudes and language policies through different approaches and perspectives that contemplate themes such as borders, teaching, resistance, time, space, identity and religion.

Regarding the organization of this dossier, it took place in a historic moment of great uncertainty and instability caused by the Covid-19 pandemic, which led us to the emergence of ruptures in models of doing and socializing research, as well as challenging us daily, to think about new configurations in the way we relate and connect. In view of this, we emphasize that, despite the difficulties of remote work in the midst of the accumulation of 
Dossiê: Atitudes Linguísticas e Políticas Linguísticas: abordagens interdisciplinares

demands of different orders on the part of everyone who was engaged and involved in the construction of this dossier (authors-researchers, anonymous reviewers from Brazil and abroad, the journal's technical staff, editors and organizers), we have completed this intense work that poses us with questions, reflections and perspectives for the continuity of research in the field of linguistic attitudes and policies.

Following this dossier, journal Ideação continues with articles of its continuous demand, with various studies developed in the areas of knowledge related to the scope of this journal.

We wish you a good reading!

\author{
Isis Ribeiro Berger, Phd \\ UNIOESTE - Foz do Iguaçu
}

UNESCO Chair on Language Policies for Multilingualism

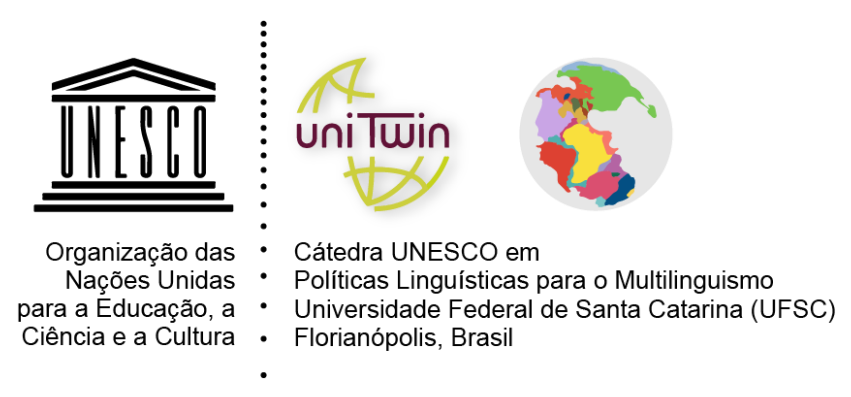

